\title{
The Importance of Irrational Purchasing Behaviour in Applying the Marketing Strategy of Selected Global Brands
}

\author{
David Vrtana ${ }^{1, *}$ \\ ${ }^{1}$ University of Zilina, Faculty of Operation and Economics of Transport and Communications, \\ Department of Economics, Univerzitna 1, 01026 Zilina, Slovakia
}

\begin{abstract}
.
Research background: The progress of business activity depends on current trends in customer shopping behavior in a global environment. The current trend is also becoming a factor of irrationality, which enters the process of purchasing behavior. It is supported by the emotions and desires of consumers. In this sense, it is important to understand the irrational behavior of customers and respect the individual behavioral characteristics in the sales process. By respecting these characteristics, a company can strengthen its brand and marketing strategy with a view to gaining a global competitive advantage. Research will highlight the importance of irrational customer behaviour between the global Lindt and Hershey brands. We will find out whether the pricing policy and the discount are important for influencing shopping behaviour. Purpose of the article: In the article, we pointed out the importance of behavioral characteristics of irrational shopping behaviour in the abovementioned global brands. We will confirm whether the research of Dr. Ariely and despite the current trends, irrationality prevails in shopping behaviour in the environment of Slovak customers. Methods: In order to assess the theoretical assumptions of behavioral economics and irrational shopping behavior, we used methods of analysis, synthesis. In the analytical part of the article, we also used the method of sociological questioning in order to ensure the credibility of the entire research. In the discussion part of the article, we used the method of induction.

Findings \& Value added: Pointing out the importance and connection of irrational purchasing behavior in the application of the company's marketing strategy in a global market environment.
\end{abstract}

Keywords: purchasing behaviour, behavioral economics, Hershey, Lindt, marketing strategy

JEL Classification: $M 32 ; M 37$

\footnotetext{
*Corresponding author: david.vrtana@,fpedas.uniza.sk
} 


\section{Introduction}

The use of elements of psychology in economic theories is currently a trend that companies are trying to use to influence shopping behavior. An important element of behavioral economics is to understand a person and explain his fluctuations in behavior and especially in the decision-making process. This means that the behavioral economy does not perceive man from a rational point of view.

Currently, there are a number of views that characterize the behavioral economy. Schwartz argues that it is based on assertions that reflect the results of psychological research into human behavior and results from the social sciences and biology. [1] Baddeley argues that this type of economy extends economic principles to social and psychological influences. According to the author, these are important for purchasing decisions. [2] Based on the above views, it can be argued that the principle of behavioral economics is based on economic foundations. Social and psychological aspects are an important element. These are important when making purchasing decisions. Hollowel argues that such principles can also strengthen customer loyalty to the brand. [3] A similar opinion is expressed by Valaskova and Krizanova, who claim that it is possible to strengthen customer loyalty through the quality services offered. [4] We agree with this view because the quality of services provided can be reflected in the application of the principles of behavioral economics.

Based on the above principles of behavioral economics, we decided to confirm or refute the above statements. The subject of the article is research carried out in the form of sociological questioning of the questionnaire technique, in which we focus on two global brands. These are the Hershey and Lindt brands, and we are investigating whether the "free effect" according to Dan Ariely's 2009 research is still valid. Our research supports the principle of behavioral economics based on the decision-making process in uncertain situations. We prove that even a small reduction in price and the so-called The "free effect" can have a major impact on consumers' shopping behavior. Subsequently, in the discussion part, we focused on the marketing impact of the principles of behavioral economics and we generalize our results for the Slovak market.

\section{Baseline situation}

As already mentioned in the introduction of the chapter, the subject of the article will be the analysis of two global brands Lindt \& Sprüngli and Hershey Company. Lindt \& Sprüngli is a Swiss company with a long tradition, whose object of activity is to offer the highest quality chocolate. The brand has international operations in approximately 120 countries around the world through subsidiaries and distribution companies. Currently, the brand is considered a leader with premium chocolate and belongs to the category of the most innovative and creative companies. The innovation is characterized by quality technologies for processing cocoa beans.

The marketing strategy of the Lindt \& Sprüngli brand is focused on the quality of the products offered. It is secured by two factors. The first is that the subject of the company is the orientation and specialization in chocolate. The second factor is related to the production process. As part of the company's production process, every part of the process is carefully monitored, from the selection of the best cocoa to the finished product. In addition to product quality, the company's marketing strategy is focused on offering traditional products and introducing many innovations. The tradition of the products is supposed to evoke memories in the form of nostalgia. External product communication is also part of the marketing strategy. This consists mainly in the visual design of the 
packaging. The result of the brand's marketing strategy is the successful satisfaction of the customer's needs with quality and traditional products. [6]

The success of the brand is also proved by numbers. The brand currently employs approximately 14,600 people and has sales outlets in more than 500 countries around the world. The brand is most successful in the markets of Japan and Brazil. At present, the brand has a market share of $5.1 \%$. [7]

The second global brand that is the subject of our research focus is Hershey. Hershey Company is an American international company based in Pennsylvania and is one of the largest chocolate manufacturers in the world. In addition to chocolate, the brand's product portfolio also includes bakery products (biscuits, milkshakes, cakes and many more). The company operates in more than 60 countries around the world.

Part of the marketing strategy is to focus on history, as the company has been operating on the market for more than 125 years. The element that distinguishes the brand from others is the specific taste of chocolate, which differs significantly from well-known European brands. Part of the brand's marketing strategy is to penetrate new markets with new products with new innovative elements. The brand currently employs approximately 18,000 people. Compared to the Lind brand, the company has a higher market share of $7.2 \%$. $[8,9]$

The fundamental difference between the Lindt and Hershey brands is the pricing policy of the products. The Lindt brand is considered a premium brand and therefore the price of their products is higher. The average price of Lindoor products is $\$ 25.99$. The average price of Lindt chocolate is $\$ 6$. The average price of Hershey chocolate is $\$ 2.24$. The price difference between the products is on average $\$ 3.76$ per product. Based on the above price difference, we decided to examine the principle of behavioral economics, the so-called "free effect".

The free effect is currently considered an excellent marketing move that can influence a large number of customers. Vlaskova et al. Also agrees with this opinion in her research. al. They argue that it is important to use the right marketing tool for the customer's decision. [10] One of them may be the free effect. Ariely investigated this effect in his experiment. If the customer notices the "free" offer, he stops thinking rationally and starts focusing on the product marked "free". The author further claims that in many cases the customer buys products that he does not even really need. Ariely incorporated this effect into a simple experiment with the above-mentioned brands Hershey and Lindt.

At the beginning of the experiment, he drew attention to the quality of individual chocolates and observed whether the quality will be taken into account by the respondents when buying. Lindt chocolate is characterized by its high quality, unlike the Hershey brand. In the first part of the experiment, he set the prices at which he would sell chocolates. Lindt sold chocolates for $€ 0.15$ and Heshey chocolate cost $€ 0.01$. The result was higher sales of Lindt products as the quality of the brand was justified. Subsequently, Ariely carried out the second round of the experiment, where he reduced the price by $€ 0.01$. In this case, the Lindt product was sold for $€ 0.14$ and the Hershey product for $€ 0$ - free of charge. The result of the second part of the experiment was significantly different from the first. In the second part, respondents did not appreciate the quality of the products and bought the Hershey brand more. The difference in these results was in the form of a free effect. The performed experiment confirmed the effect of irrational behavior. If we find ourselves in situations where it is much more attractive for us to get something for free even at the price that we will not be satisfied with the product, we still want it. [11]

Based on the above experiment, we decided to either confirm or refute the results of the author Ariella by our research. The aim of the research is to point out the importance and significance of the influence of the behavioral principle on the irrational behavior of 
customers in the implementation of the purchasing decision between the Lindt and Hershey brands.

\section{Materials and Methods}

As mentioned in the previous chapter, the subject of research is irrational behavior in the marketing environment of the Lindt and Hershey brands. The aim of the research is to point out the importance and significance of the behavioral principle of the "free effect" on the irrational behavior of customers in making the purchasing decision between the Lindt and Hershey brands.

We carried out the research through non-standardized sociological questioning using the questionnaire technique. Individual questions were closed, in which the respondents had to choose one of the offered options. The full wording of the experiments, with the same products and prices, we left in two questions. The questionnaire contained 6 questions divided into three parts. The first part of the questionnaire was identification data, where we found out the gender and age of the respondents. The second part of the questionnaire focused on questions related to shopping behavior. The individual questions were focused on determining the frequency of purchase of consumer products. We also found out whether the respondents always make the purchase rationally or unplanned (irrational), to what extent the respondents are influenced by the factors when making the purchase. In the last part of the questionnaire, we directed questions to products from the Hershey and Lindt brands.

The statistical set is represented by consumers aged 15 and over making purchasing decisions. The statistical unit consists of 1 Slovak consumer. The questionnaire was distributed in personal form in the form of an interview with the respondent. The expected return of the questionnaire was 150 respondents. The actual return was 100 respondents. We carried out the research from 1.7.2020 - 31.8.2020.

\section{Results}

Due to factors, we observed a change in the change in the rational behavior of the respondents. The task of the built-in effects was to confirm or refute the irrational behavior of consumers and to compare the resulting values with the values of the Dan Ariely experiment.

As mentioned in the previous chapter, 100 respondents participated in the research. The distribution of respondents by gender and age is in the following table.

Table 1. Demographic distribution of respondents.

\begin{tabular}{|c|c|c|c|c|c|c|}
\hline Age & $\begin{array}{c}\text { Number of } \\
\text { respondents }\end{array}$ & $\begin{array}{c}\text { Percentage } \\
\text { share }\end{array}$ & Woman & $\begin{array}{c}\text { Share in \% of } \\
\text { the total } \\
\text { number of } \\
\text { woman }\end{array}$ & Men & $\begin{array}{c}\text { Share in \% of } \\
\text { the total } \\
\text { number of men }\end{array}$ \\
\hline to 25 & 66 & $66 \%$ & 41 & $66.13 \%$ & 25 & $65.79 \%$ \\
\hline $26-40$ & 22 & $22 \%$ & 11 & $17.74 \%$ & 11 & $28.95 \%$ \\
\hline $41-55$ & 12 & $12 \%$ & 10 & $16.13 \%$ & 2 & $5.26 \%$ \\
\hline Sum & $\mathbf{1 0 0}$ & $\mathbf{1 0 0} \%$ & $\mathbf{6 2}$ & $\mathbf{1 0 0} \%$ & $\mathbf{3 8}$ & $\mathbf{1 0 0} \%$ \\
\hline
\end{tabular}

The table above shows that 62 women and 38 men took part in the study. According to the table, the most numerous category of respondents were women under the age of 25.

In the third question, we asked how often respondents purchase everyday consumer products. Out of the total number of 100 respondents, 61 respondents stated that they 
purchase everyday consumer products several times a week. Four respondents stated that they make a purchase once a month, 25 respondents make it once a week and 10 respondents every day. From the results, it can be stated that most respondents stated that they make purchases several times a week. This is a sufficient result for examining the irrational level in purchasing behavior.

Questions 4 and 5 focused on rational and irrational purchasing behavior. In them, we found out whether the respondents always make their purchases rationally or prefer spontaneous purchases. Both questions also included an explanation of the terms used. After analyzing the results, we found that respondents prefer impulsive shopping behavior. As many as 66 respondents expressed their preference for spontaneous, unintentional shopping behavior (even under the influence of emotions). Out of the total number, 53 respondents stated that they perform rational shopping behavior only occasionally.

In the sixth question, we focused on identifying the factors that influence rational shopping behavior. The basic factors included the following: discounts, the urgency of the situation, current advertising, the opportunity to get something for free, low product prices. We have evaluated these factors as those that can trigger impulsive shopping behavior. We were interested in how respondents evaluate these factors. They were to assign numbers to the individual factors on a scale from 1 to 5 , where 1 represents the least influencing value and 5 the most influential value. The results of this question can be seen in the following figure 1 .

\section{Factors influencing impulsive shopping behavior}

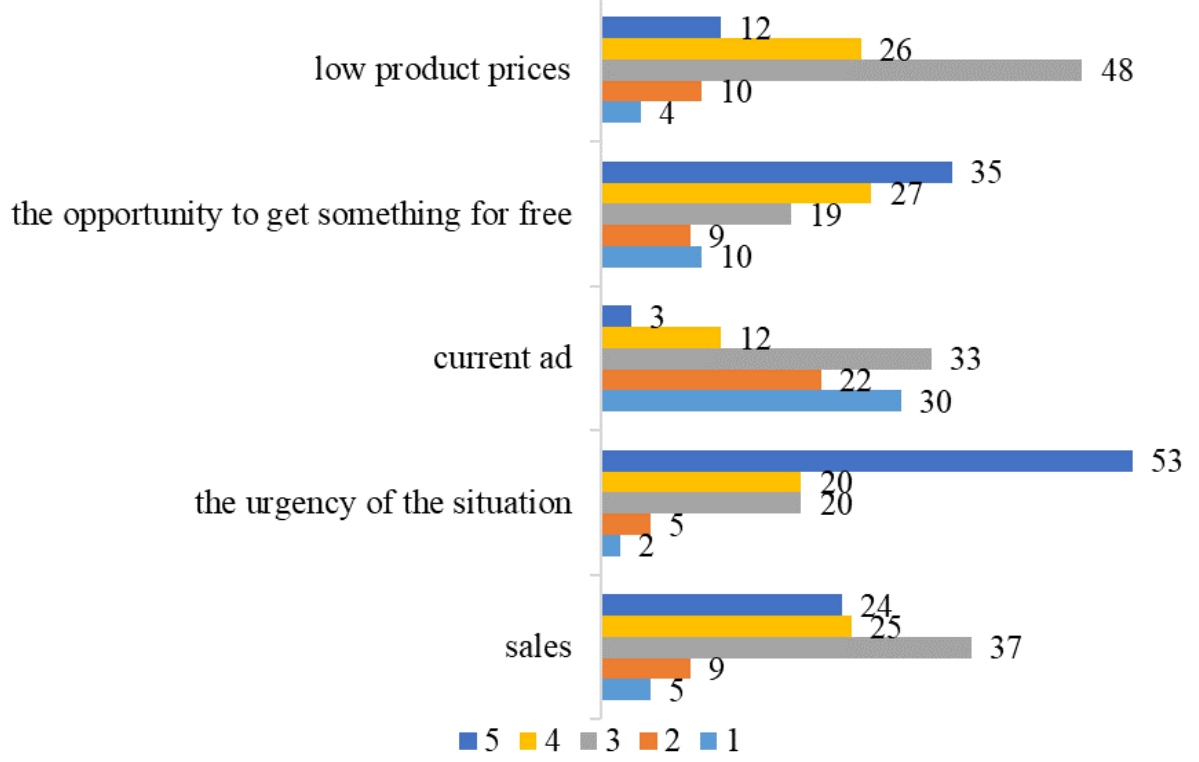

Fig. 1. Factors influencing impulsive shopping behavior.

The above chart shows that the urgency of the situation is a factor that can influence impulsive shopping behavior. This result can be considered as expected as there is a general assumption that we act impulsively in an emergency. Discounts and low product prices are 
another factor that significantly influences impulsive shopping behavior. The free effect was also a highly rated factor that determines the impulsiveness of our shopping behavior.

The last two questions were focused on monitoring the response of respondents to individual offers. Respondents had no idea that these were psychological issues on the basis of which they should act irrationally. These questions were identical to Dan Ariely's experiment. The questions were two product offers. In question 8 , respondents had to choose between $€ 0.15$ Lindt chocolate and $€ 0.01$ Hershey chocolate. In question 9, we chose the same chocolates, but we reduced the price in direct proportion to $€ 0.01$. The chocolates on offer were as follows: Lindt for $€ 0.14$ and Hershey for $€ 0$ - free of charge. Respondents' answers are shown in the following graphs. [9]

\section{Chocolates Lindt and Hershey}

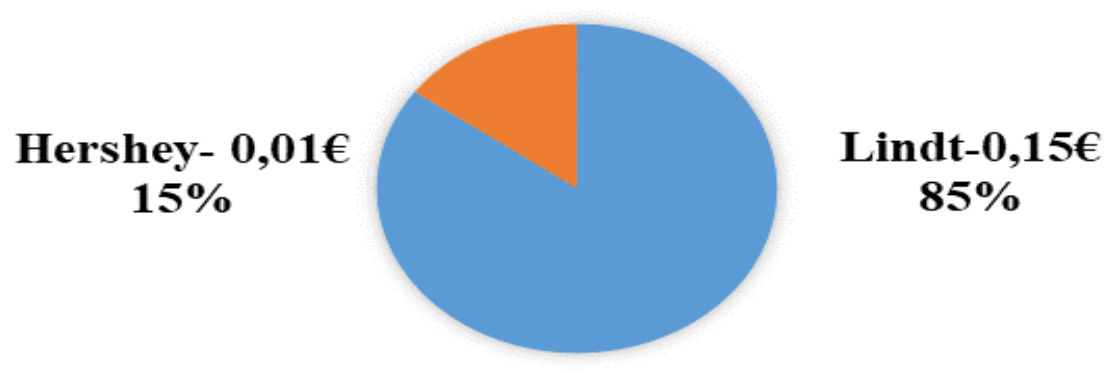

Fig. 2. Chocolates Lindt and Hershey.

\section{Chocolates Lindt and Hershey-effect free}

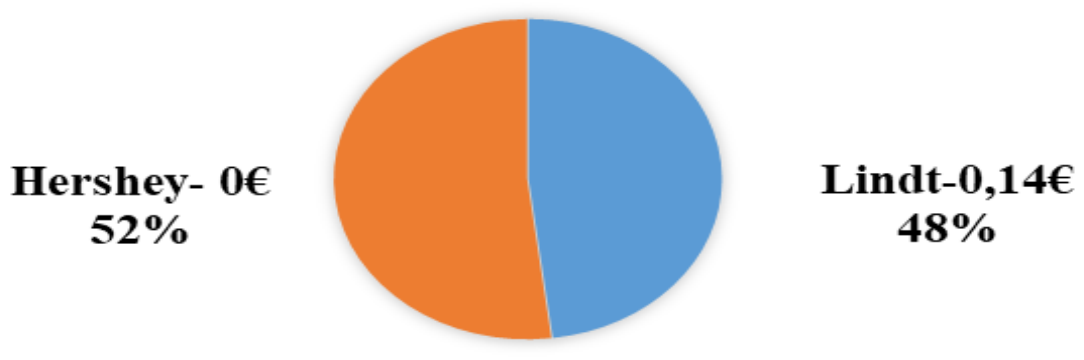

Fig. 3. Chocolates Lindt and Hershey - effect free.

The result in Figure 8 confirms the results of Dan Ariely's experiment. The larger respondents in this case acted rationally and preferred products with higher quality. It was the Lindt brand. Economic theory assumes that a directly proportional reduction in the price of products should not change consumers' shopping behavior. In the second question, we directly reduced the price of the products by $0.01 €$. According to general economic theory, 
there should be no change in purchasing behavior. The result can be seen in Chart 9. The directly proportional reduction in price caused a "free effect". This means that up to 52 respondents preferred the Hershey brand, and only because it was free.

\section{Discussion}

Based on the results of research, it can be assumed that currently the behavioral economy is of fundamental importance in the field of marketing and business management. Its use and importance in the field of marketing strategy represents a potential for the company to gain a competitive advantage. This fact can be generalized in the international understanding. The above statement is also confirmed by the authors Zeman and Bogdan. [12]

Our research has confirmed the statements of the already implemented experiment of Dan Ariely from 2009. This means that this effect is still valid, but it is possible to say that the current marketing impact is even more pronounced. With it, sellers try to influence the purchasing decision in favor of their own products and services.

Consumer shopping behavior is more irrational. Spontaneously reckless behavior is triggered by various impulses (eg the investigated effect for free). Therefore, in this part of the article, we decided to present two proposals by which companies can greatly strengthen product sales. The first suggestion is the limitation of selection paralysis. This is a rule that should determine the quantity of the assortment offered. This rule should be followed by most traders. If a company offers a large number of products and discounts, it can have the exact opposite effect for the customer, which was the goal of the company. Such an impact can have a negative effect on customer behavior. If the consumer does not get into a situation where he will not be able to choose, the company can focus even more on a narrower selection of assortment and discounts. This also creates space for the introduction of any effects that evoke impulsive behavior (eg the already mentioned effect for free). It is possible to achieve such impulsive behavior in customers with a limited amount of the offered assortment. The authors Krizanova, Gajanova and Nadanyiova also agree with this opinion. [13] In case of restrictions, it may also use elements of exclusivity or introduce a limited purchase option. The aim is to stimulate people's fear of possible loss and thus force them to make the purchase itself. According to Nadanyi, neuromarketing is also crucial in the study of irrationality. [14]

The second proposal is the creation of benefits within the creation of offers. In this regard, it is necessary to take into account two factors, which are sympathy and reciprocity. In the context of sympathy, it is important to make a first impression. This should relate to the characteristics on the basis of which the customer builds a positive relationship with the brand or product. [15] One of the traits can be authenticity and humanity. Appropriately chosen method of communication can not only convince the consumer of the purchase but also positively influence his decision-making process. This factor can be used intensively by e-shops in the form of fast delivery of goods, gifts to buy and the like. In this context, digital technologies should be part of the marketing strategy. Their importance for marketing strategy in the concept of irrational behavior is emphasized by the author Tuffnell et al. [16] A similar view is presented by Buno et al. [17]

The second factor is reciprocity. The fact that a company decides to provide something to the customer for free, or to use an occasional system of discounts as part of its pricing policy, may have a suggestive effect on the consumer. Discounts can make the purchase decision more impulsive. The aim of the factor is to ensure consumer satisfaction with the product or brand. The recommendation points to a close relationship between business and consumer. This can also be created by the influence of a correctly applied form of marketing communication of the company towards the consumer. [18,19] Because a 
company that offers a wide range of benefits to the consumer evokes a feeling of kindness in the customer and thanks to this feeling, it can respond positively and do what is required of him. In this context, reciprocity can also occur through the use of the word of mouth marketing tool. According to Chankoson and Thabhiranrak, this form of marketing can contribute to better reciprocity between business and customer and between customers and each other. [20]

\section{Conclusion}

At present, it is possible to perceive the constant development and improvement of technology, which makes things easier from everyday life. As people adapt to new innovations and improvements, so do businesses try to respect current trends. One of them is the use of elements of behavioral economics. The basic determining feature of the behavioral economy is the area of limited rationality in the decision-making process. Human decision-making, which has become the subject of interest in behavioral economics, is greatly influenced not only by emotions, but also by the various factors that have been the subject of this article. From the results, it can be argued that behavioral economics is important in building a good business name. If a company decides to introduce elements of psychology and knowledge of behavioral economics into its marketing strategy, it can build a strong competitive advantage in the market. It will thus achieve the desired impulsive behavior of consumers, which can then easily influence and use to its advantage. The individual elements can be used by the company regardless of its operation. For example, the element of social approval or the free effect can be used not only at the domestic level, but also at the international level. This means that the principles of behavioral economics are generally applicable to the Japanese and American style of business management. [20]

This paper is an output of scientific project VEGA no. 1/0718/18: The impact of psychographic aspects of pricing on the marketing strategy of companies across products and markets.

\section{References}

1. Schwartz, H. (2008). A guide to behavioral economics. Virginia: Higher Education Publications.

2. Baddeley, M. (2017). Behavioural economics: A very short introduction. New York, NY: Oxford University Press.

3. Hollowell, J.C., Rownlad, Z., Kliestik, T., Kliestikova, J., Dengov, V.V. (2019). Customer loyalty in the sharing economy platforms: How digital personal reputation and feedback systems facilitate interaction and trust between strangers. Journal of SelfGovermance and Management Economics, 7(1), 13-18.

4. Valaskova, M., Krizanova, A. (2008). The passenger satisfaction survey in the regional integrated public transport system. Promet-Traficc \& Transportation, 20(6), 401-404.

5. Kriaznova, A. (2008). The current possition and perspecives of the integrated transport systems in Slovak republic. Eksploatacja I Niezawodnosc-Maintenance and Reliability, 4, 25-27.

6. Lindt, Maitre chocolatier suisse depuis 1845. (2018, June 6). About us. LINDT and SPRUNGLI. Retrieved from : https:/www.lindt-spruengli.com/about-us/lindt/.

7. Schmid, S. (2018, March 4). Annual report-Research \& Development. . LINDT and SPRUNGLI. Retrieved from : https://www.lindtspruengli.com/fileadmin/user_upload/corporate/user_upload/Medias/Publications/Lead 
_Stories_Annual_Report/Focus_Annual_Report_2018_Research_Development_ENG. pdf.

8. Hersheyes company. (2019, June 4). Annual report. The Hershey Company. Retrieved from https://www.thehersheycompany.com/en_us/home.html

9. Lewis, R. (2016, February, 5). Hershey company. Britannica. Retrieved from: https://www.britannica.com/topic/Hershey-Chocolate-Corporation

10. Valaskova, K., Kliestikova, J., Krizanova, A. (2018). Consumer perception of private label products: An empirical research. Journal of Competitiveness, 10(3), 149-163.

11. Ariely, D. (2009). How expensive is free. Slovakia : Premedia.

12. Zeman, Z. Bogdan, A. (2019). Marketing strategy and building brand value on the Hungarian market. Ekonomicko-manazerske spektrum, 13(2), 1-9.

13. Krizanova, A., Gajanova, L., Nadanyiova, M. (2019). Design of a CRM level and performance measurement model. Sustainability, 10(7), 2567.

14. Nadanyiova, M. (2017). Neuromarketing - An opportunity or a threat? Communications: Scientific Letters of the University of Zilina, 19(4), 90-94.

15. Rosnerova, Z. (2020). The impact of globalization on the business position of European Union. In T. Kliestik, $19^{\text {th }}$ International scientific Conference Globalization and its Socio-economic Consequences 2019- Sustainability in the Global-Knowledge economy (pp. 25 - 35). Rajecke Teplice.

16. Tuffnell, C., Kral, P., Siekelova, A., Horak, J. (2019). Cyber-Psychical Smart Manufacturing Systems: Sustainbale Industrial Networks, Cognitive Automation, and Data-Centric Business Models. Economics, Management and Financial Markets, 14(2), 58-63.

17. Buno, M., Nadanyiova, M., Hraskova, D. (2015). The comparison of the quality of business environment in the countries of Visegrad group. K. Kocisova \& A. Tartalova, Conference: 4th World Conference on Business, Economics and Management WCBEM (pp. 423-430). Turkey: Procedia Economics and Finance.

18. Zauskova, A., Reznickova, M. (2020). SoLoMo marketing as a global tool for enchancing awareness of eco-innovations in Slovak business environment. Equilibrium. Quarterly Journal of Economics and Economic Policy, 15(1), 133-150.

19. Majerova, J., Krizanova, A., Zvarikova, K. (2013). Social media marketing and possibilities of quantifying its effectiveness in the process of brand value building and managing. 9th International Scientific Conference on Financial Management of Firms and Financial Institutions Location (pp. 476 - 485). Ostrava.

20. Chankoson, T., Thabhiranrak, T. (2019). The moderating role of brand awareness between the relationship of emotional attachment, brand relationship and positive word of mouth. Polish Journal of Management Studies, 20(1), 129-138.

21. Nadanyiova, M. (2014). Japanese Management and its practice in company branch based in Slovakia. Conference: 8th International Scientific Conference on Business and Management (pp. 546-554). Lithuania : Business and Management . Spausdinta. 